\title{
Metal nanoparticles with biocide properties. Potential uses for food preservation
}

\section{Salvatore Parisi* \\ Industrial Consultant, Palermo, Italy}

Food companies face different challenges on the international level at present when speaking of food safety, consumer acceptation, and regulatory compliance [1-4]. The complexity of current food-related problems can be really difficult because of the interconnection of many variables. In fact, the food industry is one of the main vital sectors of the current industrial world. The necessity of fast and immediately available food commodities in many Countries has to be seriously taken into account as one of the main pressure elements when speaking of social equilibrium and antagonist effects [5-7].

In general, food safety and public health issues concern the following arguments and topics: microbiological contaminations, detection of unallowed and/or probably undesired chemical compounds perceived as "foreign constituents", non-food related physical contamination (wood, metals, glass, plastic matters, radioactivity), intentional (economically motivated) food adulteration, etc. [8-10]. On the other hand, it should be admitted that the main perceived risk by food consumers is related to food illnesses with microbial causes. In fact, the First Law of Food Degradation clearly implies that food products are irreversibly modified during time with various effects, including perishability as the result of microbial spreading and consequent food unacceptability [11-14].

As a clear result, many efforts have been reported so far with concern to antimicrobial activity of certain additives in foods. The use of antibiotics and similar compounds as food additives or preservative agents has been studied with interesting and promising results: certain natural substances such as chitosan may be considered for similar purposes because of their broad spectrum action and the possible incorporation in the plastic matrix of packaging materials [15-18]. On the other side, the psychological impact of these compounds on the behaviour of food consumers and the real effects on human health should be considered carefully.

Another strategy against microbial (degradative and pathogen) agents may consider the use of metal nanoparticles as part of current food safety strategies [19-21]. The antimicrobial role of certain metals and related compounds is known from centuries: in addition, antifungal and insecticide properties have been extensively reported so far. In particular, the following metals and metal oxides - silver and silver dioxide, silicon and silicon dioxide compounds (in association with silver or gold also), calcium and magnesium oxides, copper monoxide, gold, titanium dioxide, and zinc oxide, - have been repeatedly studied and considered as possible antimicrobial agents, although it should be considered that similar compounds may have other technological roles without food safety relation [22-24].

Silver and silver-based nanoparticles are extensively reported in the scientific literature because of their strong antimicrobial properties
[25-26]. Apparently, these features are linked to the observed damage of outer microbial membranes and interfering activity against normal metabolic processes by means of the interaction with enzymatic sulfhydryl or disulfide groups [19,27-28]. In addition, the reduced dimension of nanoparticles seems to enhance antimicrobial properties; as a result, the interest in silver and silver oxide $\left(\mathrm{Ag}_{2} \mathrm{O}\right)$ nanoparticles has been notably increased in recent years. Finally, silver appear to show less toxic effects if compared with other sustances able to fight microbial activity [19]. However, other metal or metal oxide-based nanoparticles side (silicon and silicon dioxide, gold) can be helpful in this ambit because of their recognized antimicrobial activity on the one hand and their non-toxic features with relation to human safety on the other side. For these reason, correlated researches could be extremely useful in this ambit $[19,29]$.

\section{References}

1. Parisi S (2016) The World of Foods and Beverages Today: Globalization, Crisis Management and Future Perspectives. Learning.ly/ The Economist Group. [Crossref]

2. Parisi S, Barone C, Sharma RK (2016) Chemistry and Food Safety in the EU: The Rapid Alert System for Food and Feed (RASFF). SpringerBriefs in Chemistry of Foods, Springer International Publishing, Cham. [Crossref]

3. Pisanello D (2014) Chemistry of Foods: EU Legal and Regulatory Approaches SpringerBriefs in Chemistry of Foods, Springer International Publishing, Cham.

4. Parisi S (2017) Antimicrobials in foods today and the role of chitosan - current hopes and new perspectives. Glob Drugs Therap 2: 114. [Crossref]

5. Hartmann M (2011) Corporate social responsibility in the food sector. Eur Rev Agric Econ 38: 297-324. [Crossref]

6. Testart A, Forbis RG, Hayden B, Ingold T, Perlman SM, et al. (1982) The Significance of Food Storage Among Hunter-Gatherers: Residence Patterns, Population Densities, and Social Inequalities [and Comments and Reply]. Curr Anthropol 23: 523-537. [Crossref]

7. Pivato S, Misani N, Tencati A (2008) The impact of corporate social responsibility on consumer trust: the case of organic food. Business Ethics: A European Review 17: 3-12. [Crossref]

8. Delgado A, Parisi S, Barone C, Vaz Almeida MD (2016) Leguminosas na dieta mediterrânica - nutrição, segurança, sustentabilidade. Conferencia de Inovação e Segurança Alimentar, Instituto Politécnico de Leiria, 05 ${ }^{\text {th }}$ May 2016, Leiria, Portugal.

9. Mania I, Barone C, Caruso G, Delgado A, Micali M, et al. (2016) Traceability in the Cheesemaking Field. The Regulatory Ambit and Practical Solutions. Food Qual Mag 3: 10-20. [Crossref]

10. Mania I, Fiorino M, Barone C, Barone M, Parisi S (2016) Traceability of Packaging Materials in the Cheesemaking Field. The EU Regulatory Ambit. Food Packag Bull 25: 11-16. [Crossref]

Correspondence to: Parisi S. Industrial Consultant, Palermo, Italy, E-mail: drparisi@inwind.it

Received: July 22, 2017; Accepted: August 21, 2017; Published: August 23, 2017 
11. Parisi S (2002) I fondamenti del calcolo della data di scadenza degli alimenti: principi ed applicazioni. Ind Aliment 41: 905-919. [Crossref]

12. Parisi S (2013) Food industry and packaging materials-performance-oriented guidelines for users. Smithers Rapra Technology, Shawbury.

13. Steinka I, Barone C, Parisi S, Micali M (2017) Instrumental Systems for the Control of Frozen Vegetables During Refrigeration. In: Steinka I, Barone C, Parisi S, Micali M (Eds) The Chemistry of Frozen Vegetables. SpringerBriefs in Chemistry of Foods, Springer International Publishing, Cham. Switzerland. pp: 31-36. [Crossref]

14. Volpe MG, Di Stasio M, Paolucci M (2015) Polymers for food shelf-life extension. In: Cirillo G, Spizzirri UG, Iemma F (eds) Functional polymers in food science: from technology to biology. vol 1: food packaging. Scrivener Publishing, Beverly.

15. Del Nobile MA, Gammariello D, Conte A, Attanasio M (2009) A combination of chitosan, coating and modified atmosphere packaging for prolonging Fior di latte cheese shelf life. Carbohydr Polym 78: 151-156. [Crossref]

16. Goosen MF (Ed) (1996) Applications of Chitan and Chitosan. CRC Press, Boca Raton. [Crossref]

17. Mu H, Zhang A, Zhang L, Niu H, Duan J (2014) Inhibitory effects of chitosan in combination with antibiotics on Listeria monocytogenes biofilm. Food Control 38: 215-220. [Crossref]

18. Luo Y, Wang Q (2013) Recent advances of chitosan and its derivatives for novel applications in food science. J Food Process Beverages 1:1-13. [Crossref]

19. Dizaj SM, Lotfipour F, Barzegar-Jalali M, Zarrintan MH, Adibkia K (2014) Antimicrobial activity of the metals and metal oxide nanoparticles. Mat Sci Eng C 44: 278-284. [Crossref]
20. Shi LE, Li ZH, Zheng W, Zhao YF, Jin YF, et al. (2014) Synthesis, antibacterial activity, antibacterial mechanism and food applications of $\mathrm{ZnO}$ nanoparticles: a review. Food Add Contam A 31: 173-186. [Crossref]

21. Amna T, Hassan MS, Yousef A, Mishra A, Barakat NAM, et al. (2013) Inactivation of foodborne pathogens by $\mathrm{NiO} / \mathrm{TiO} 2$ composite nanofibers: A novel biomaterial system. Food Bioproc Technol 6: 988-996. [Crossref]

22. Dekkers S, Krystek P, Peters RJB, Lankveld DPK, Bokkers BGH, et al. (2011) Presence and risks of nanosilica in food products. Nanotoxicology 5: 393-405. [Crossref]

23. Palza H (2015) Antimicrobial polymers with metal nanoparticles. Int J Mol Sci 16 : 2099-2116. [Crossref]

24. Zimmermann MB, Hilty FM (2011) Nanocompounds of iron and zinc: Their potentia in nutrition. Nanoscale 3: 2390-2398. [Crossref]

25. Allahverdiyev AM, Abamor ES, Bagirova M, Rafailovich M (2011) Antimicrobial effects of $\mathrm{TiO} 2$ and $\mathrm{Ag} 2 \mathrm{O}$ nanoparticles against drug-resistant bacteria and leishmania parasites. Future Microbiol 6: 933-940. [Crossref]

26. Zinjarde SS (2012) Bio-inspired nanomaterials and their applications as antimicrobial agents. Chronicles Young Sci 3: 74. [Crossref]

27. Egger S, Lehmann RP, Height MJ, Loessner MJ, Schuppler M (2009) Antimicrobia properties of a novel silver-silica nanocomposite material. Appl Environ Microbiol 75: 2973-2976. [Crossref]

28. Lok CN, Ho CM, Chen R, He QY, Yu WY, et al. (2006) Proteomic analysis of the mode of antibacterial action of silver nanoparticles. J Proteome Res 5: 916-924. [Crossref]

29. Elsaesser A, Howard C (2012) Toxicology of nanoparticles. Adv Drug Deliv Rev 64 129-137. [Crossref]

Copyright: (C2017 Parisi S. This is an open-access article distributed under the terms of the Creative Commons Attribution License, which permits unrestricted use, distribution, and reproduction in any medium, provided the original author and source are credited. 